\title{
CORRIGENDUM
}

\section{Large negative thermal expansion of a polymer driven by a submolecular conformational change}

Xingyuan Shen, Christopher Viney, Erin R. Johnson, Changchun Wang and Jennifer Q. Lu

Nature Chemistry 5, 1035-1041 (2013); Published online 20 October 2013; corrected after print 22 April 2014.

In the version of this Article previously published, some incorrect data were included in Fig. 1e. The initial data were inadvertently repeated as the data for 20,000 cycles, and the total number of cycles was stated as 50,000 when it should have been 43,000. An error corresponding to the latter was also made in the first full sentence on page 1037. Figure 1e should have appeared as shown below. These errors have been corrected in the online versions of the Article.

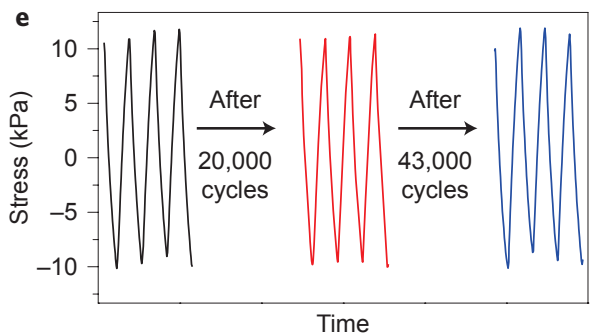

\section{ADDENDUM}

\section{Diversity in the dynamical behaviour of a compartmentalized programmable biochemical oscillator}

Maximilian Weitz, Jongmin Kim, Korbinian Kapsner, Erik Winfree, Elisa Franco and Friedrich C. Simmel

Nature Chemistry 6, 295-302 (2014); Published online 16 February 2014; corrected after print 22 April 2014.

The authors wish to add the following to the Acknowledgements section of this Article 'E.F. and F.C.S. gratefully acknowledge funding from the Bavaria California Technology Center (BaCaTeC).' The online versions of the Article have been amended accordingly.

\section{ADDENDUM}

\section{Exceptionally fast carbon-carbon bond reductive elimination from gold(III)}

W. J. Wolfe, M. S. Winston and F. D. Toste

Nature Chemistry 6, 159-164 (2014); published online 22 December 2013; corrected after print 22 April 2014.

In our Article we described the preparation and observation in situ of a complex of the type $\left[\mathrm{Au}(\operatorname{aryl})_{2} \mathrm{Cl}\left(\mathrm{PPh}_{3}\right)\right]$, which is similar to a series of cyclometallated $\mathrm{Au}(\mathrm{III})$ complexes that undergo aryl-aryl and aryl-alkyl reductive elimination reported in two papers that we inadvertently omitted from our reference list:

Vicente, J., Bermudez, M. D., Escribano, J., Carrillo, M. P. \& Jones, P. G. Synthesis of intermediates in the C-H activation of acetone with 2-phenylazophenylgold(III) complexes and in the $\mathrm{C}-\mathrm{C}$ coupling of aryl groups from diarylgold(III) complexes. Crystal and molecular structures of $\left[\mathrm{Au}\left\{\mathrm{C}_{6} \mathrm{H}_{3}\left(\mathrm{~N}=\mathrm{NC}_{6} \mathrm{H}_{4} \mathrm{Me}-4^{\prime}\right)-2-\mathrm{Me}-5\right\}(\right.$ acac-C) $\mathrm{Cl}](\mathrm{acac}=$ acetylacetonate $)$, cis- $\left[\mathrm{Au}\left(\mathrm{C}_{6} \mathrm{H}_{4} \mathrm{~N}=\mathrm{NPh}-2\right) \mathrm{Cl}{ }_{2}(\mathrm{PPh})\right]$ and $\left[\mathrm{Au}\left(\mathrm{C}_{6} \mathrm{H}_{4} \mathrm{CH}_{2} \mathrm{NMe}_{2}-2\right)\left(\mathrm{C}_{6} \mathrm{~F}_{5}\right) \mathrm{Cl}\right]$. J. Chem. Soc. Dalton Trans. 3083-3089 (1990).

Vicente, J., Bermudez, M. D. \& Escribano, J. Gold in organic synthesis. preparation of symmetrical and unsymmetrical biaryls via C-C coupling from cis-diarylgold(III) complexes. Organometallics 10, 3380-3384 (1991). 